\title{
Konaklama İşletmelerinin Turist Rehberleri Şikayetleri Üzerine Bir Araştırma: Safranbolu Örneği
}

\section{A Research on Tourist Guides Complaints of Accommodation Enterprises: The Case of Safranbolu}

\author{
Dr. Öğr. Üyesi Tolga Fahri ÇAKMAK \\ Zonguldak Bülent Ecevit Üniversitesi, Karadeniz Ereğli Turizm Fakültesi, Türkiye \\ Zonguldak Bülent Ecevit University, Faculty of Tourism, Turkey \\ E-Mail: tolgafahricakmak@gmail.com \\ Dr. Öğr. Üyesi Hande AKYURT KURNAZ \\ Bolu Abant İzzet Baysal Üniversitesi, Turizm Fakültesi, Türkiye \\ Bolu Abant İzet Baysal University, Faculty of Tourism, Turkey \\ E-Mail: handekurnaz@ibu.edu.tr
}

$\ddot{O} \mathbf{z}$

Amaç ve Önem: Bu çalışmanın amacı konaklama işletmelerinin, turist rehberlerine yönelik şikayetlerinin araştırılması ve incelenmesidir. Gerçekleştirilen tur faaliyetlerinde turist rehberi olmazsa tur gerçekleşememektedir bu da turun konakladığ 1 otel ile turist rehberi arasındaki etkileşimi mecburi kılmaktadır. Çalışma bu sebeple oteller ve turist rehberleri arasında yaşanan sorunların oteller açısından değerlendiriliyor olması noktasında önem taşımaktadır.

Yöntem: Çalışma nitel araştırma yöntemlerinden görüşme tekniği ile gerçekleştirilmiş olup görüşmeler yarı yapılandırılmıș soru formları ile tamamlanmıștır. Bu çerçevede yönetici ya da konaklama ișletmesi sahibi, on yıl ve üzeri meslek deneyimine sahip 16 adet katılımcı ile görüşmeler gerçekleştirilmiştir. Katılımcılardan elde edilen bilgiler betimsel analiz aracılığı ile incelenmiştir.

Bulgular: Yapılan görüşmeler çerçevesinde konaklama işletmelerinin şikayetleri turist rehberlerinin personel ile ilişkileri, konaklama işletmesi ile turist ilişkileri ve konaklama işletmesi ile acenta ilişkileri olmak üzere üç alt başlıkta incelenmiştir. Konaklama işletmelerinin özellikle turist rehberlerinin aşırı talepkar ve kaba davranışları, konaklama işletmesine dair yanlış bilgilendirme ve tur programından aykırı hareket etme davranışlarının şikayet sebebi olduğu görülmüştür.

Özgünlük/Bilimsel Katkı: Bu çalışma doğrudan sektöre yönelik bir alan araştırması olup, sektör içerisinde sürekli ilişki halinde bulunan iki meslek grubu arasındaki sorunlara odaklanmaktadır. Bu alanda çok az sayıda yayına rastlanmış olması ve turist rehberlerine yönelik otel şikayetleri üzerine herhangi bir çalışmaya rastlanmamış olması sebebi ile alan yazınına önemli bir katkı sunmaktadır.

Sınırlılıklar: Çalışma Karabük ilinin Safranbolu ilçesinde yer alan konaklama işletmeleri üzerinde uygulanmış ve buradan elde edilen sonuçlar ile tüme varıma gidilmiştir. Bu kapsamda görüşme yapılan konaklama işletmelerinin samimi görüş bildirdikleri ve çalışmanın sadece belirli bir destinasyonda gerçekleştirilmesi sınırlılıklar kapsamında değerlendirilebilir.

Anahtar Kelimeler: Turist rehberi, konaklama işletmesi, şikayet, Safranbolu.

Makale Türü: Araştırma makalesi

Atıf için (for cited); Çakmak ve Akyurt Kurnaz (2020). Konaklama İşletmelerinin Turist Rehberleri Şikâyetleri Üzerine Bir Araştırma: Safranbolu Örneği, Turist Rehberliği Dergisi, 3(2), 139-153. 
Turist Rehberliği Dergisi (TURED) \& Y1l. 2020, Cilt. 3, Sayı. 2

Journal of Tour Guiding (JOTOG) \& Year. 2020, Volume. 3, Issue. 2

\begin{abstract}
Purpose and Importance: The aim of this study is to investigate and examine the complaints of accommodation businesses against tourist guides. If there is no tourist guide in the tour activities, the tour cannot be realized, which makes the interaction between the hotel where the tour is accommodated and the tour guide. For this reason, the study is important in terms of evaluating the problems between hotels and tourist guides in terms of hotels.
\end{abstract}

Methodology: The study was carried out with the interview technique, one of the qualitative research methods, and the interviews were completed with semi-structured questionnaires. In this context, interviews were held with 16 participants who are managers or accommodation business owners and have ten years or more professional experience. The information obtained from the participants was examined through descriptive analysis.

Findings: Within the framework of the interviews, the complaints of the accommodation businesses were examined under three sub-headings: the relations of the tourist guides with the staff, the relations between the accommodation business and the tourist, and the relations between the accommodation business and agency. It has been observed that the excessively demanding and rude behavior of the accommodation businesses, especially the tourist guides, misinformation about the accommodation business and acting against the tour program are the reasons for the complaints.

Originality/Value: This study is a field study for the sector and focuses on the problems between two occupational groups that are in constant relationship within the sector. It makes an important contribution to the literature as there are very few publications in this field and no studies on hotel complaints for tourist guides have been found.

Limitations: The study was applied on the accommodation establishments located in Safranbolu district of Karabük province and the results were obtained from here. In this context, it may be considered within the scope of limitations that the accommodation businesses interviewed give sincere opinions and the study is carried out only in a specific destination.

Keywords: Tourist guide, accommodation enterprises, complaint, Safranbolu.

Paper Type: Research article

Giriş

Turizm endüstrisi ulusal, bölgesel ve yerel düzeyde, makro ölçekten mikro ölçeğe meydana gelen değişimlerin sonucu olarak gelişmekte ve çeşitlenmektedir. Bu çeşitliliğin sonucu olarak turistlerin beklentileri ve algıları sürekli olarak farklılık göstermektedir. Turizm işletmeleri açısından da turistlerin bu beklentilerine cevap vermek zorunluluğu doğmaktadır (Camilleri, 2018). Turizm endüstrisi çok paydaşlı bir sektördür. Bu paydaşlardan biri de turizm işletmeleri şeklinde karşımıza çıkmaktadır. Turizm işletmeleri içerisinde yer alan konaklama işletmeleri de büyük öneme sahip olmakla birlikte turizmin temel yapı taşlarından biridir. Son yarım yüzyılda turizm giderek daha yaygın hale gelmiş olup, turizme yönelik tutumlar da değişmiş̧ir (Foley vd., 1997). Bir turizm destinasyonu, ziyaretçilere şehrin çekici imajını, turistik deneyimlerini sunmak için ticari kuruluşların ve kurumların birlikte çalıştıkları kaynak ve cazibe merkezlerini içermektedir (Ejarque, 2005). Destinasyonlar çeşitli turizm ürünlerinden meydana gelmektedir. Turizm ürünleri doğal ve doğal olmayan unsurların birleşiminden oluşmaktadır. Turistlerin ziyaret ettikleri antik kent, hizmet satın aldıkları konaklama işletmesi, deniz gibi unsurlar turizm ürününe örnek olarak gösterilebilmektedir (Murphy, Pritchard \& Smith, 2000). Turist memnuniyeti turizm hizmetini satın alma ile ilgili olmakla birlikte hizmet kalitesinin de temelidir. Turist memnuniyeti ile ilgili sağlanan geri dönüşler hizmetlerin daha kaliteli bir şekilde sunulmasını sağlamakta ve turistlerin beklentilerinin neler olduğuna dair önemli ipuçları vermektedir. Pek çok yazar bu kavramı, 
tüketicinin beklentileri ile algılanan performans arasında yaptığı karşılaştırmanın sonucu olarak tanımlamaktadır (Oliver, 1997). Diğerleri ise memnuniyeti, ürünün beklentilerine göre nasıl algılandığını karşılaştırmaktan kaynaklanan kişisel zevk veya hayal kırıklığı duyguları olarak adlandırmaktadır (Giese \& Cote, 2000).

Turist deneyimi, destinasyonda tüketilen, çeşitli şekillerde karşımıza çıkan hizmetleri, ürünleri ve ev sahibi toplulukla olan etkileşimleri içermektedir. Başlıca turizm hizmetleri konaklama, seyahat, tur işletmeciliği, tur rehberi hizmetleri, ulaşım, yemek, dinlenme ve turistik alanlardan oluşmaktadır. Bu hizmetler içerisinde yer alan ve çeşitli bileşenlerden oluşan paket turlar, organize seyahat pazarının önemli bir bölümünü oluşturmaktadır (Çetin \& Yarcan, 2017).

Turist rehberleri, destinasyonların tanıtımında temel rol oynayan turizm çalışanlarından biridir. Turistlerle sürekli iletişim halinde olmakla birlikte farklı sorumlulukları bulunmaktadır. Turist rehberi; bölgenin kültürü, tarihi, anlamları, anlatıları ve imgeleri hakkında aktarılan bilgiler yoluyla destinasyon ortamını yeniden üretmektedir. Turistlerin zihinlerinde önemli bir resim oluşturmaktadır (Wynn, 2005). Rehberli turlar, turistlerin destinasyon özelliklerini kısa sürede ve düşük maliyetlerle kolaylıkla ziyaret edip anlamalarını sağlayan bir turizm ürünüdür ve organize turlar şeklinde gerçekleşir (Cohen, Ifergan \& Cohen, 2002). Organize tur, yerel halk aracılığıyla turizmi yönetmenin bir yoludur ve bu nedenle rehberli bir tur, herhangi bir turistin çeşitli sorunlarla karşılaşmasını engeller ya da engelleyememe durumunda da turistin sorununu çözebilmektedir. Bu sebeple organize turlar ve organize turları yöneten turist rehberleri, turistlerin, yabancı bir ortamda yaşayabilecekleri zarar verici bir olayın etkilerini azaltmaya yardımcı olmaktadır (Schmidt, 1979). Rehber, tercüman, eğitimci, ev sahibi toplumun büyükelçisi gibi farklı roller üstlenerek yerel kültür, yerli halk ve turistler arasında etkileşimi kolaylaştıran bir kişidir. Bir rehber aynı zamanda eğitmen, kültür komisyoncusu, çevirmen, hikaye anlatıcısı, akıl hocası, yol bulucu, organizatör, satış görevlisi ve karar verici olabilmektedir (Hansen \& Mossberg, 2016; Holloway, 1981; Yarcan, 2007). Lider olarak bir rehber, bir turun sorunsuz işlemesi ve müşterilerin refahı için sorumluluk alan kişi olarak da tanımlanmaktadır (Larsen \& Meged, 2013).

Turların sorunsuz bir şekilde gerçekleştirilmesi turizmde memnuniyeti sağlayan olumlu bir etkendir. Olumlu etkenlerin yanında memnuniyeti etkileyen olumsuz faktörler de bulunmaktadır ve şikayetler de bunlardan biridir. En basit tanımı ile şikayet; herhangi bir memnuniyetsizliği sözlü ya da yazılı yollarla ifade edilmesi durumudur (Kılınç, 2014). Turizm endüstrisi içerisinde acentalardan konaklama işletmelerine doğrudan ve dolaylı pek çok paydaşın bulunması, paydaşlar arası şikayetlere sebebiyet verecek durumların da çoğalmasını meydana getirmektedir. Bu durumun belirlenmesi ve çözümlenmeye çalışılması turizmde kaliteli hizmet anlayışının sağlanması açısından önemli olmaktadır. Birçok görev ve sorumluluğa sahip olan rehberler hakkında da memnuniyetsiz durumlar olabilmektedir. İster istemez karşılaşılan bu durumların belirlenmesi ve durumun düzeltilmesi gerekilmektedir.

$\mathrm{Bu}$ bağlamda yapılan çalışmanın temel konusunu konaklama işletmeleri tarafından turist rehberleri hakkında olan şikayetler oluşturmuştur. Araştırmanın temel amacı da konaklama işletmelerinin turist rehberleri hakkındaki şikayetlerinin belirlenmesidir. Bu amaç doğrultusunda verilerin toplanması için görüşme tekniği kullanılmıştır. Çalışmada nitel bir yöntem belirlenmesinin nedeni ise, turist rehberleri hakkında olan şikayetlerin derin ve yoğun bir şekilde araştırılmak istenmesidir. Araştırma kapsamında konaklama işletmelerinin hizmet verdiği destinasyon olarak Safranbolu seçilmiştir. Bu durumun nedeni de Safranbolu'nun hem günübirlik turlar hem de konaklamalı turlar açısından popüler bir gezi güzergahında ve yılın 12 ayı ziyaret edebilecek bir özelliğe sahip olmasıdır. Unesco Dünya Miras Listesi’nde 1994 
y1lından itibaren yer alan Safranbolu önemli bir turizm destinasyonudur. Konaklama işletmesi olarak çeşitli pozisyonlarda görev alan 16 kişi ile görüşülmüş olup, elde edilen veriler görüşme yöntemine uygun olarak analiz edilmiştir. Araştırmanın sonucunda da şikayetler; konaklama işletmesi yönetimi-personeli ile ilişkileri, konaklama işletmesi - turist ilişkileri ve konaklama işletmeleri - seyahat acentaları ilişkilerinde yaşanan şikayetler olarak ele alınmıştır.

\section{Turist Rehberleri ve Şikâyet}

Turizm multidisipliner bir endüstridir ve bu nedenle operasyonel faaliyetleri için birçok farklı paydaş içermektedir. Herhangi bir turistik destinasyonda, sürdürülebilir turizm gelişimi için temel unsurlardan biri aktif paydaşların katılımı ve onların işbirliğinin sağlanmasıdır. Bu paydaşlardan biri olan turist rehberleri de turizm endüstrisinde önemli bir rol oynamaktadır (Batman, vd. 2001). Turist rehberleri, turist ziyaretini unutulmaz bir deneyime dönüştürme yeteneğine sahip olsa da turist rehberlerinin kabiliyetine ek olarak, turistlerin nihai memnuniyetini etkileyebilecek hizmetleriyle ilgili sıkıntılar da olabilmektedir (Sandaruwani \& Gnanapala, 2016).

Turist rehberliği çağdaş turizmde önemli ve etkili bir role sahiptir (Kruczek, 2013). Tarihsel olarak turist rehberliği en eski faaliyetlerden biridir. Turistlerin memnuniyeti, sadece ulaşım, konaklama, yemek ve eğlence gibi ürünlerin kalitesi ile değil, aynı zamanda turistlerin güvenliğini sağlayarak programın etkin bir şekilde gerçekleştirilmesi ve uygun bir bilgi aktarımı ile belirlenmektedir. Bu nedenle, tüm turist etkinliğinin kalitesi turist rehberlerinin bilgi, deneyim, organizasyon yetenekleri ve yaratıcılığına bağlıdır (Rabotic, 2010).

Ev sahibi ülkenin resmi olmayan elçileri olarak turist rehberlerinin temel ön koşulları, dürüstlük, alçakgönüllülük, haysiyet ve güvenilirlik dahil olmak üzere olumlu kişisel özelliklere, etik ve ahlaki kavramlara sahip olmalarıdır. Kapsamlı bilgi ve konuyu güçlü bir şekilde kavrama, iyi analitik beceriler, tarihi kültürel alanlar için karşılaştırmalı bir bakış açısı, sürekli öğrenmeye ve kişisel zenginleşmeye bağl1lık gibi entelektüel nitelikler eşit derecede önemlidir. Dahası, temel mesleki nitelikler arasında ziyaretçinin dilinde gerçekleri anlatma ve sunma yeteneği, grupları yönetme ve organize etme kapasitesi, doğru duruş ve göz teması ile hikaye anlatma yeteneği yer almaktadır (Sandaruwani \& Gnanapala, 2016).

Turizmin temel yapı taşlarından biri olan turist rehberlerinin pek çok rolü bulunmaktadır. Buna ek olarak zaman içerisinde de yeni roller ortaya çıkmıştır. Bilginin yayılması, eğitim ve turist gruplarından sorumlu olmakla ilişkili geleneksel rollerin yanı sıra, bir turist aktivisti ve turist uzmanı gibi yeni roller meydana gelmiştir (Kruczek, 2013).

Turizm endüstrisinin karmaşıklığı, turizm hizmetlerinin tüketimini anlamay1 zorlaştırmaktadır. Böylesine zorlu bir sektörde, tüketim sonrası davranışlar da farklılık göstermektedir (Cohen, 2004). Bu davranışlardan bazıları turistler tarafından yapılan şikayetlerden, bazıları da sektörde yer alan paydaşlar tarafından gelen şikayetlerden oluşmaktadır (Ekiz vd., 2012). Kavram olarak şikayetler, karşılanmamış beklentilerin ifadesidir. Müşteriler memnun olmadıklarında şikayeti doğrudan yönetime, dolaylı olarak misafir kartlarına, şikayet ve öneri formlarına yazarak, olayları arkadaşlarına ve ailelerine anlatarak olumsuz durumları paylaşmaktadır (Petriana, 2015). Şikayetlerle mümkün olan ilk fırsatta etkili bir şekilde ilgilenmemek, değerli müşterilerin kaybına, bazen de bir işletmeye olumsuz tanıtıma veya başka zararlara neden olabilmektedir (WALES, 2016).

En verimli turizm işletmesinin bile, tesisleri, ürünleri veya çalışanları tarafından müşterilere sağlanan hizmetlerle ilgili bazı şikayetler alması muhtemeldir. Özellikle memnun olmayan müşterileri belirlemenin ve şikayetleri etkili bir şekilde ele almanın, turizm işletmesi açısından birçok faydası bulunmaktadır. Bunlar (WALES, 2016); 
Turist Rehberliği Dergisi (TURED) \& Y1l. 2020, Cilt. 3, Sayı. 2

Journal of Tour Guiding (JOTOG) \& Year. 2020, Volume. 3, Issue. 2

- Hataları düzeltme veya sorunları çözme firsatı sağlama,

- Müşteri deneyimini iyileştirmek için kullanılabilecek değerli geri bildirimler elde etme,

- Küçük zorlukların büyük sorunlara dönüşmesini durdurma,

- Tekrar eden iş düzeylerini artırma,

- Şikayetlerinin nasıl ele alındığından memnun olan müşterilerden olumlu bildirim alma,

- Aynı sorunun tekrar ortaya çıkmasını durdurma firsatı elde etmektir.

Şikayet kavramı sadece turizm işletmelerini ilgilendiren bir konu değildir. Turizm sektörü içerisinde hem işletmeler hem de turistlerle sürekli etkileşim halinde olan turist rehberleri hakkında da şikayetler söz konusudur. Özellikle bu şikayetlerin işletmeler tarafından yapılması, turist rehberleri açısından önemli bir sorun olarak değerlendirmelidir çünkü turist rehberleri, rehberlik hizmetlerini büyük oranda turizm işletmeleri aracıllğı ile gruplara sunmaktadır. Bu durumda şikayet kavramının belirlenmesi, nedenlerinin araştırılması ve şikayetler konusunda önlemlerin alınması turist rehberlerinin istihdamı, işletmelerin geleceği, turistlerin memnuniyeti, kaliteli hizmetin gerçekleştirilmesi açısından önem taşımaktadır. Alan yazınında ağırlıklı olarak turist rehberlerine yönelik internet tabanlı, eşikayetlerin değerlendirilmesine rastlanmaktadır (Avc1 \& Doğan, 2018; Kanlı, 2019; Temizkan \& Ar, 2017; Yetgin vd., 2018), bu çalışmalarda turist rehberlerine yönelik şikayetlerin ağırlıklı olarak, turist rehberinin turu yönetmede yetersiz kalması, yaşanan aksaklıkları gruba yansıtması, tur planı dışında davranması, sorumsuz ve kaba davranışları merkezli olduğu görülmektedir.

$\mathrm{Bu}$ şikayetler turistler tarafından yapılacağı gibi, turist rehberlerinin birebir iş akışında yer alan seyahat acentaları ve konaklama işletmeleri tarafindan da yapılması da muhtemel bir sonuçtur. Burada önemli olan şikayet konularının belirlenmesi ve en kısa sürede çözümünün gerçekleştirilmesidir. E-şikayet odaklı çalışmalardan farklı olarak Çakmak ve Akyurt Kurnaz (2020) yaptıkları çalışmada seyahat acentalarının turist rehberlerine yönelik şikayetlerinin incelendiği görülmektedir. Bu çalışmada da turist rehberlerinin destinasyona hâkim olmama, anlatım yapmaya istekli olmama ve şahsi menfaat merkezli davranışların acentalar tarafından şikayet edildiğinin altı çizilmektedir.

\section{Safranbolu Destinasyonu}

Dünya ekonomisi içerisinde yer alan önemli sektörlerinden biri de turizmdir. Zaman içerisinde de birçok değişimlere sahne olmuştur. Özellikle geçmiş dönemlerde sadece üst gelir grubunun gerçekleştirdiği bir faaliyet olan turizm; günümüzde her türlü gelir grubuna hitap eden, şehirleşmenin etkisiyle doğaya kaçışın gerçekleştiği, geniş kitlelerin katıldığı, eğitim, eğlence ve dinlenme başta olmak üzere çeşitli amaçlarla gerçekleşen bir ekonomi haline gelmiştir. $\mathrm{Bu}$ gelişim doğrultusunda turistlerin beklentileri ve turizm ürün tercihleri de değişmiş̧ir. Turistlerin ilgilerinin değişmesiyle turizm çeşitliliği de artmıştır. Bu çeşitlilik içerisinde kültürel turizm ayrı bir yere sahip olmuştur (Özdemir, 2011).

$\mathrm{Bu}$ çalışmanın da gerçekleştirildiği bölge olan Safranbolu ilçesi kültür turizmi açısından oldukça önemli bir destinasyondur. Hem tarihi hem de doğal güzellikleri popüler bir destinasyon olan Safranbolu, Unesco Dünya Mirası Listesinde yer alan merkezlerden biridir. 17. ve 18. yüzyıl dönemine ait Osmanlı sivil mimarisini örneklerinin günümüzde hala bölgede izlenebiliyor olması, tarihi evlerin ve mahallelerin özgünlüğünü koruyan yapısı turistik açıdan da önemli bir cazibe merkezi özelliği sunmaktadır (Yazıcıŏglu, 2001). Öte yandan bölgede bulunan Bulak Mencilis Mağarası, Tokatlı Kanyonu gibi değerler bölgede gerçekleştirilen 
Turist Rehberliği Dergisi (TURED) \& Y1l. 2020, Cilt. 3, Sayı. 2

Journal of Tour Guiding (JOTOG) \& Year. 2020, Volume. 3, Issue. 2

turizm faaliyetlerinde alternatif turizm türleri açısından çeşitlilik sağlamaktadır (Ceylan \& Somuncu, 2016).

Türk kentsel tarihi içerisinde iyi derecede korunmuş örneklerinden biri olan Safranbolu'nun sahip olduğu ahşap, taş ve kerpiç malzemelerin kullanılmasıyla inşa edilen konak benzeri karkas evleri, çeşmeleri, hamamları, hanları, camileri, çarşısı, tarihi ve kültürel şehir görüntüsüyle, sit alanı olarak ilan edilmiş bir merkezdir. Ahşap Türk mimarisinin bozulmamış örneklerinden Safranbolu yerli ve yabancı birçok turist ağırlamaktadır. Batı Karadeniz bölgesinin önemli bir turizm merkezi olan Amasra'nın da aynı güzergahta olması Safranbolu açısından turizme katkı sağlamaktadır. Ayrıca İstanbul ve Ankara gibi büyükșehirlere olan yakınlığı, ulaşım imkanlarının mevcut durumu Safranbolu'da turizmin gelişimine yardımcı olmaktadır (Özdemir, 2011; Yazıcıŏglu, 2001).

Tarihsel süreç olarak; Anadolu'nun kuzeybatı kesiminde yer alan Paphlagonia şeklinde adlandırılmış bölgede Safranbolu yer almaktadır. Geçmişi M.Ö. 3000'li yıllara dayanmaktadır. Bu bölge Kızılırmak ve Filyos arasında yer almaktadır. Hititler, Frigler, dolaylı bir şekilde Lidyalılar, Persler, Pondlar, Romalılar, Selçuklular, Çabanoğulları, Candaroğulları ve Osmanlı İmparatorluğu'nun egemenlikleri altında yer almıştır. Türklerin egemenliğine Melik Muhiddin Mesut tarafından 1196 yılında geçmiştir. Bu bağlamda tarih süresince Safranbolu, birçok uygarlığa ev sahipliği yapmıştır. Böylelikle kültürel çeşitliliği de görmek mümkündür (Safranbolu Turizm Danışma Bürosu, 2020).

Safranbolu Batı Karadeniz Bölgesinde yer almaktadır. Coğrafi yapı bakımından engebeli bir özelliği bulunmaktadır. Karasal iklimden etkilenen Karadeniz iklimi hakimdir. Bitki örtüsü orman olup, tarım alanları da yer almaktadır. Yerel halkın yaşamını en iyi yansıtan evleridir. Geniş, 2-3 kattan oluşan, ahşap ve kerpiçten yapma evler hem ulusal hem uluslararası alanlarda Safranbolu Evleri olarak bilinmektedir (Karabük Valiliği, 2020).

Böyle bir tarihi ve coğrafi dokuya sahip olan Safranbolu, Kent Tarihi Müzesi, Kaymakamlar Evi Müzesi, Saat Kulesi, Tarihi Cezaevi, Cinci Han-Hamamı, YemenicilerDemirciler arastaları, Hıdırlık Tepesi, Güneş Saati ve Muvakkithane, Köprülü Mehmet Paşa, İzzet Mehmet Paşa, Dağdelen, Hidayetullah ve Kaçak (Lütfiye) adında yer alan camileri, Bulak Mencilis Mağarası, İncekaya Su Kemeri, Cam Teras, Yörük Köyü, Türk Kahve Müzesi ve Tabakhane Müzesi gibi önemli turizm çekim merkezleri ile farklı turizm türlerine ev sahipliği yapan bir destinasyondur. Cinci Han ile İpek Ticaret Yolu'nun Safranbolu'dan geçmesiyle ticari açısından önemli bir merkez olmuştur. Böylelikle geleneksel el sanatları açısından da gelişmiştir. Ayrıca Safran, Safranbolu'ya adını veren bitkidir. Safranın kullanıldığ 1 çeşitli gastronomi temelli turlar yapılmaktadır. Baharat ve gıda boyası olarak kullanılan bu bitki sayesinde çeşitli hasat turları ile Safranbolu turizmine katkı sağlanmaktadır (Safranbolu Turizm Danışma Bürosu, 2020).

Tablo 1: Safranbolu Turist Verileri

\begin{tabular}{|c|c|c|c|}
\hline Yll & Yerli & Yabancı & Toplam \\
\hline $\mathbf{2 0 1 5}$ & 190.111 & 53.996 & 244.107 \\
\hline $\mathbf{2 0 1 6}$ & 173.075 & 32.069 & 205.144 \\
\hline $\mathbf{2 0 1 7}$ & 217.842 & 57.917 & 275759 \\
\hline $\mathbf{2 0 1 8}$ & 218.584 & 97.258 & 315842 \\
\hline
\end{tabular}

Kaynak: Safranbolu Turizm Danışma Bürosu, 2020. 


\section{IIIIII}

Turist Rehberliği Dergisi (TURED) \& Y11. 2020, Cilt. 3, Sayı. 2

Journal of Tour Guiding (JOTOG) \& Year. 2020, Volume. 3, Issue. 2

Safranbolu sahip olduğu kültürel ve doğal güzellikleri sayesinde yerli ve yabanc1 turistler tarafından ziyaret edilmektedir. Yıllar itibariyle giderek artışın olduğu tabloda görülmektedir. Safranbolu hem konaklamalı hem de günübirlik rotası sayesinde yerli turistlerin ilgi odağ olmaktadır. Bunun en temel sebebi Safranbolu ile birlikte Amasra gibi yerlerinde paket turlar içerisinde olmasıdır. Yabancı turistlerin milliyetlerine bakıldığında genellikle Çin ve Tayvan'ın ilk iki sırayı paylaştığı bilinmektedir. Bu açıdan kültürel rotaların önemli bir temsilcisinin Safranbolu olduğunu belirtmek yanlış bir tanım olmamaktadır.

\section{Araştırmanın Amacı ve Yöntemi}

$\mathrm{Bu}$ çalışmada konaklama işletmeleri tarafından turist rehberlerine yönelik dile getirilen şikayetlerin araştırılması amaçlanmıştır. Alan yazınında konunun internet tabanlı şikayetler ağırlıklı olarak ele alındığ 1 (Kanlı, 2019; Yetgin vd., 2018), sektör içerisinde sürekli ilişki halinde olunan diğer işletmelerin turist rehberlerine yönelik şikayetlerinin yeteri kadar çalışılmadığ1 görülmektedir. Bu konuda Çakmak ve Akyurt Kurnaz (2020) tarafından gerçekleştirilen çalışma diğer paydaşlar üzerinde uygulandıkça turist rehberleri açısından daha bütüncül bir şikayet yönetimi yapısı ortaya çıkacaktır. Ayrıca bu çalışma oteller ve turist rehberleri arasındaki sorunların oteller açısından değerlendirilmesi hususunda da önem arz etmektedir.

Çalışma nitel araştırma yöntemleri çerçevesinde hazırlanmış olup bu kapsamda tüme varım mantığı üzerine kurulmuştur. Veriler yüz yüze görüşme yöntemi ile elde edilmiş, yarı yapılandırılmış görüşme tekniği kullanılmıştır. Bilimsel araştırmalarda görüşmeler önceden gerçekleştirilen ciddi hazırlıklar eşliğinde, belirli bir plana dayalı ve etkileşim merkezli, derinlemesine bilgi alma hususunda en çok kullanılan yöntemlerdendir (Yıldırım ve Şimşek, 2016). Bu çalışmada da şikayete sebep olan davranışların derinlemesine irdelenmesi amacı ile tercih edilmiştir. Bu sebeple aşağıdaki sorular katılımcılara yöneltilmiştir:

- Turist rehberlerinin, işletmeniz yönetimi ve personeli ile olan ilişkilerinde hangi davranışlarından şikayetçisiniz?

- Turist rehberleri, işletmenizin turistler ile olan ilişkilerinde şikayete sebebiyet verecek ne gibi davranışlarda bulunmaktadır?

- İşletmenizin seyahat acentaları ile olan ilişkilerinde turist rehberlerinin hangi davranışlarından şikayetçisiniz?

Çalışma katılımcılarının belirlenmesinde amaçlı örneklem yöntemi kullanılmıştır. $\mathrm{Bu}$ yöntemde araştırmacılar, elde edilmek istenen bilgiye ulaşılabilecek çeşitli ölçüt ve kıstasların belirlemektedir. Bu yönü ile olasıllk temelli olmayan bir örneklem belirleme şeklidir (Patton, 2005). Amaçlı örneklem yöntemi kapsamında katılımcılardan, Safranbolu bölgesinde bir konaklama işletmesi sahibi olmak veya bölgedeki bir konaklama işletmesinde ön büro müdürü olarak çalışmak ve konaklama sektörü içerisinde en az 10 yıllık tecrübeye sahip olma kriterleri aranmıştır. Aranan kriterler 1şığında kartopu örneklem yöntemi ile 24 adet katılımcı adayına ulaşılmış bunlardan 16 tanesi görüşmeyi kabul etmiştir. Yapılan görüşmeler 03.04.2020 05.07.2020 tarihleri arasında online görüntülü konferans aracıllğı ile her bir katılımcı ile birebir görüşmeler şeklinde tamamlanmış, her görüşme 40 dakika ile sinırlandırılarak gerçekleştirilmiştir. Elde edilen verilerin analizinde betimsel analiz yöntemi kullanılmıştır Betimsel analizde belirlenen temalar kapsaminda toplanan verilerin özetlenip yorumlanmas1 gerekmektedir. Burada araştırmacı görüşlerini çarpıcı bir biçimde yansıtabilmek amacıyla doğrudan alıntılara sık sık yer vermektedir (Yıldırım ve Şimşek, 2016). Bu çalışmada da hem doğrudan görüşlere sıklıkla yer verilmiş hem de görüşmecilerin en sık dile getirdiği sorun ve şikayetler benzerliklerine göre tablolar halinde gruplanmıştır. 
Turist Rehberliği Dergisi (TURED) \& Yı1. 2020, Cilt. 3, Sayı. 2

Journal of Tour Guiding (JOTOG) \& Year. 2020, Volume. 3, Issue. 2

\section{Bulgular}

Yapılan görüşmelerde öncelikli olarak katılımcıların konaklama işletmesindeki rolleri, meslekteki deneyim süreleri ve konaklama işletmesinin türü sorulmuştur. Tablo 2, bu sorulara verilen yanıtlardan oluşturulmuştur.

Tablo 2: Katılımc1 Bilgileri

\begin{tabular}{|c|c|c|c|}
\hline $\begin{array}{c}\text { Katılımeı } \\
\text { No }\end{array}$ & $\begin{array}{c}\text { Görüşülen Konaklama İşletmesi } \\
\text { Görevlisi }\end{array}$ & $\begin{array}{c}\text { Meslekteki deneyim } \\
\text { süresi }\end{array}$ & $\begin{array}{c}\text { İşletme } \\
\text { Türü }\end{array}$ \\
\hline K 1 & Ön Büro Müdürü & 10 & Otel \\
\hline K 2 & İşletme Sahibi & 11 & Konak \\
\hline K 3 & Ön Büro Müdürü & 14 & Otel \\
\hline K 4 & Ön Büro Müdürü & 10 & Konak \\
\hline K 5 & İșletme Sahibi & 12 & Otel \\
\hline K 6 & İşletme Sahibi & 15 & Konak \\
\hline K 7 & Ön Büro Müdürü & 18 & Konak \\
\hline K 8 & İșletme Sahibi & 15 & Konak \\
\hline K 9 & Ön Büro Müdürü & 14 & Konak \\
\hline K 10 & İşletme Sahibi & 12 & Otel \\
\hline K 11 & İşletme Sahibi & 13 & Otel \\
\hline K 12 & Konak Sahibi & 11 & Konak \\
\hline K 13 & İşletme Sahibi & 10 & Otel \\
\hline K 14 & Ön Büro Müdürü & 11 & Otel \\
\hline K 15 & İșletme Sahibi & 15 & Otel \\
\hline K 16 & İşletme Sahibi & 16 & Otel \\
\hline
\end{tabular}

Tablo 2'yi incelediğimizde 16 adet konaklama işletmesi ile görüşme sağlanmıştır. Görüşülen işletmelerde, görüşme yapılan kişilere baktığımızda 6 katılımcı ön büro müdürü iken 10 katılımcı işletme sahibidir. İşletmelerin ise Meslek deneyim sürelerinin 10 ile 18 yıl arası değişmektedir. Görüşme yapılan işletme türlerinden 9 turizm işletme belgeli 7 işletme belediye işletme belgelidir.

\subsection{Konaklama İşletmesi yönetimi ve personel ile ilişkiler}

Turist rehberlerinin grupları ile birlikte otele girdiklerinde ilk gerçekleştirdikleri eylem otel yönetimi ve personel ile iletişime girmektir. Bu süreç grubun otobüsten ayrilıp konaklama işletmesine yerleşmesi, grubu bilgilendirme, odaların dağıtımı gibi pek çok aşamayı içerdiği gibi aslında konaklama işletmesinden çıkana kadar devam etmektedir. Yani turist rehberi konaklama işletmesine giriş sürecinden çıkana kadar konaklama işletmesi personeli ile sürekli bir iletişim halindedir. Bu iletişim şekli sözlü olabildiği gibi jest ve mimiklerden görsel açıdan da gerçekleşmektedir. Bu noktada çalışma kapsamında katılımcılara turist rehberlerinin otel yönetimi ve personeli ile olan ilişkileri ile bu ilişkiler süresince yaşanan sorunlar ve şikayet sebepleri sorulmuştur.

Tablo 3: Konaklama işletmesi yönetimi ve personel ile ilişkilerinde yaşanan şikayetler

\begin{tabular}{|c|l|c|}
\hline Taraflar & \multicolumn{1}{|c|}{ Şikayet } & Katılımcı Sayısı \\
\hline \multirow{3}{*}{$\begin{array}{c}\text { Konaklama İşletmesi } \\
\text { Yönetimi ve Personeli } \\
\text { ilişkileri }\end{array}$} & Aşırı talepkar & 12 \\
\cline { 2 - 3 } & İş veren gibi davranma & 11 \\
\cline { 2 - 3 } & Kaba & 9 \\
\cline { 2 - 3 } & Oda beğenmeme & 7 \\
\cline { 2 - 3 } & Otel kurallarını kırma çabası & 6 \\
\hline
\end{tabular}


Turist Rehberliği Dergisi (TURED) \& Y1l. 2020, Cilt. 3, Sayı. 2

Journal of Tour Guiding (JOTOG) \& Year. 2020, Volume. 3, Issue. 2

Tablo 3 incelendiğinde katılımcıların turist rehberlerinin otel yönetimi ve personel ile olan ilişkilerinde belirttikleri şikayetlerinde en çok belirtilen şikayetler listelenmiștir. Buna göre "aşırı talepkar" davranış 12 farklı katılımcı tarafından tekrarlanarak en çok şikayet edilen konu olmuştur. Onu "iş veren gibi davranma" davranışı izlerken "kaba tavırlar", "oda beğenmeme" ve "otel kurallarını kırma" çabası da diğer şikayet konu başlıkları olmuştur.

Dile getirilen şikayetler ile ilgili çeşitli yorumlar aşağıda verilmiştir:

"Bizi en çok rahatsız eden konu, her turist rehberi için demiyorum tabi ama bazıları gerçekten çok kaba. Aşırı bir memnuniyetsizlik. Turda ya da acenta ile yaşadı $\breve{g}$ sorun olduğu çok belli bunu daha otele girer girmez belli ediyor sanki sorunun kayna $\breve{g}$ otelmiş gibi davranabiliyor. ” K3

"Aşııl ve bedelsiz talepler ile karşılaşıyoruz. Neticede burası ufak bir işletme ve bizde elbette acenta ve rehberlere karşı normal fiyat politikası uygulamıyoruz, asgari ölçüde her türlü hizmete zaten para ödemiyorlar. Fakat bazı rehberlerimiz gerçekten abartıyor. Sürekli bir talep.” K5

"Her otel zaten turist rehberlerini rahat ettirecek şekilde onlara hizmet etmeye çallşlyor. Çok harika rehberleri ağırliyoruz hatta geldiklerinde mutlu oluyoruz, fakat bazıları da tam tersi. Sürekli ekstra talepler. Burası ticari bir işletme free ancak bir seviyeye kadar gerçekleşebiliyor ama kimi durumlarda bunu anlatmakta gerçekten sorun yaşlyor sıkıntı çekiyoruz. Bazen acenta ile konu ile ilgili görüşmek durumunda bile kalabiliyoruz" $\mathbf{K} \boldsymbol{6}$

"Öncelikle belirmem lazım sürekli bu bölgede çalışan rehberlerimiz ile çok az sorun yașlyoruz. Bölgeyi iyi bilmeyen, turist grup yapısı bir anda değișen ve ilk defa konaklamaya gelen rehberler genelde daha çok sorun potansiyeline sahip. Örneğin her otelin belirli kurallar var, oda servisi, alkol vs. biz tabi bunlara misafirler gibi rehberlerinde saygl göstermesini bekliyoruz ama kimi rehberler o kuralları sadece misafirler için olduğunu düşünüyor ve tepki gösteriyor" $\mathbf{K} 9$

"Vallahi bazı rehberlerimiz geldiğinde otelin sahibi ben değil de sanki oymuş gibi oluyor. Personele emirler, azarlamalar neler neler. Bir yere kadar müsaade ediliyor elbette bu tavirlara." K11

"Şimdi biz nasll otelci olarak konaklama ile ilgilenip tura dair rehbere bir şey ögretmeye çalısmiyorsak, rehberlere Safranbolu'yu nasıl gezdireceklerini anlatmıyorsak, rehberlerden de aynısı beklerim. Bazı rehber arkadașlar turlardaki öz güvenden olsa gerek her işi ögretmeye o kadar meraklı ki, sanki ișletmenin sahibi oymuş gibi davranıyor" K14

"Bölgedeki en iyi mutfaklardan birine sahibiz. Elbette damak tadı kişiden kişiye değişir ama kimi rehberler arkadaşlar az daha güven bulsa mutfağa girip personele yemek nasil yapılır, safran mutfakta nasil kullanilır bunu anlatacak. Bilgi ve kültürlerine saygımız sonsuz ama bazen terazinin dengesi şaşlyor sanki K15

\subsection{Konaklama İşletmesi ve Turist İlişkileri Açısından}

Çalışmanın bu kısmında konaklama işletmelerine, turistler ile aralarında gerçekleşen iletişim hususunda turist rehberlerinin oynadığ $\mathrm{rol}$ ve bu role dair şikayetleri sorulmuştur. Nasıl turist rehberleri ve konaklama ișletmeleri arasındaki iletișim otele girme sürecinde başlayıp çıkıs süreci ile sona eriyorsa turistler aşamasında da konaklama işletmesi açısından durum aynıdır. Fakat burada kişi sayısı olarak çok daha büyük bir grup söz konusudur. 
Turist Rehberliği Dergisi (TURED) \& Y1l. 2020, Cilt. 3, Sayı. 2

Journal of Tour Guiding (JOTOG) \& Year. 2020, Volume. 3, Issue. 2

Konaklama işletmelerinin turistler ile ilişkileri noktasında turist rehberlerine yönelik getirdikleri şikayetler bu kapsamda tablo 4'de verilmektedir.

Tablo 4: Konaklama işletmesi ve turist ilişkilerinde yaşanan şikayetler

\begin{tabular}{|c|l|c|}
\hline Taraflar & \multicolumn{1}{|c|}{ Şikayet } & Katılımcı Sayısı \\
\hline \multirow{3}{*}{$\begin{array}{c}\text { Konaklama işletmesi ve } \\
\text { Turist ilişkisi }\end{array}$} & Yetersiz veya yanliş bilgilendirme & 11 \\
\cline { 2 - 3 } & $\begin{array}{l}\text { Turist sorunlarında yapıcı olmama }- \\
\text { ilgilenmeme }\end{array}$ & 8 \\
\cline { 2 - 3 } & Turisti kışkırtma & 6 \\
\hline
\end{tabular}

Yapılan görüşmelerde konaklama işletmelerinin turistler ila olan ilişkilerinde

"Hatalı bilgilendirmeden çok şikayetçiyiz. Örneğin Safranbolu'da kimi otellerde dışarıdan yemek söylenmesinde sakınca yoktur çünkü zaten konaklamaya göre dişarıdan yemek söylenmekte ama bizde böyle bir durum söz konusu değil. Rehber buna alıştı̆̆ i için hiç bize sormadan turiste bu konuda bilgi veriyor. Sonra turist dlşarıdan sipariş verdiğinde biz zor durumda kaltyoruz." K1

"Rehberlerin bizden hiçbir bilgi almadan odalar, verilen hizmetler ve benzeri şeylerle ilgili turisti hatalı beklentiye sokması bizim için ciddi bir sorun. Bir defa belirli bir konuda beklenti oluşunca o beklentinin eksikliği çok daha göze battyor.” K2

"En büyük sıkıntılardan biri rehberin yaşanan sorunlara karşı ilgisizliği. Misafirlerimizle bazen sorunlar yaşayabiliyoruz rehberin burada arabulucu görevi üstlenmesi gerekirken bazen o kadar ilgisiz davranıyorlar ki bu çok can sıkabiliyor." K7

"Turist ile yaşadı̆̆ımız kimi anlaşmazlıklarda bırakın yatıştırmayı turisti daha da kışkırtan ve bizi zor durumda bırakan rehberler ile karşılaşıyoruz." $\mathbf{K} 9$

"Bölgeyi bilmeyen ya da tanımayan turist bazen yabancısı olduğu şeyleri bir sorun olarak algilayabiliyor. Böyle zamanlarda rehberler bizim için çok önemli çünkü onun desteği sayesinde turistler daha anlayışlı olabiliyor. Fakat bu olmadı̆̆ında sorunlar gerçekten büyüyor. Bir kişi ile başlayan sorun gruba yansiyor o da otelde tüm pozitif havayı değiştirebiliyor. Böyle anlarda rehberlerin hiç oralı olmaması, ara bulucu rolünü üstlenmemesi gerçekten bir sorun unsuru haline gelebiliyor." K10

"Rehber acenta ile sorunlu ya da kaptanla sorunlu olduğunda turisti de kışkırtma yoluna gidiyor kimi durumlarda. Yaşanan her sorun ya aksiliği misafirlere öyle bir sunuyor ki sanki ortada çok büyük bir mesele var." K13

\subsection{Konaklama İşletmesi ve Seyahat Acentası İlişskileri Açısından}

Bir tur organizasyonu sürecinde konaklama işletmesi ve seyahat acentası arasındaki ilişki konaklama işletmesinin turist rehberi ya da turist ile olan ilişkisinden daha kapsamlı ve daha önce başlamaktadır. Turun daha oluşum sürecinde acenta konaklama işletmesi ile gerekli iletişimi sağlayarak ayarlamaları yapar. Turun bitmesi sonrası ise turistlerden gelecek tepkilere ve şikayetlere göre iki işletme arasındaki ilişkiler tekrardan şekillenebilir. Bu açıdan bakıldığında bu işletme grupları arasındaki süreç hem turdan önce başlar hem de tur bittikten sonra da devam eder. Dolayısı ile turist rehberi veya turist grubu ile yaşanan sıkıntılar ve bu taraflardan acentalara gelecek geri dönüşler son derece önemlidir. Bu hassas yapının da farkında olan otel işletmelerinin turist rehberleri ile olan ilişkilerinde seyahat acentasını da ilgilen kısımlar özellikle katılımcılar tarafından belirtilmiştir. 
Turist Rehberliği Dergisi (TURED) \& Y1l. 2020, Cilt. 3, Sayı. 2

Journal of Tour Guiding (JOTOG) \& Year. 2020, Volume. 3, Issue. 2

Tablo 5: Konaklama İşletmeleri ve Seyahat Acentaları İlişkilerinde Yaşanan Şikayetler

\begin{tabular}{|l|l|c|}
\hline \multicolumn{1}{|c|}{ Taraflar } & \multicolumn{1}{|c|}{ Şikayet } & Katılımcı Sayısı \\
\hline \multirow{2}{*}{$\begin{array}{l}\text { Konaklama İșletmesi ve } \\
\text { Seyahat Acentaları İlişkisi }\end{array}$} & Acentaya farklı bilgi aktarımı & 11 \\
\cline { 2 - 3 } & Tur programına aykırı hareket etme & 8 \\
\cline { 2 - 3 } & Farklı otel talebi & 3 \\
\hline
\end{tabular}

Tablo 5'de Konaklama işletmelerinin acentalar ile ilişkileri hususunda turist rehberlerinin oynadığı role yönelik şikayetleri belirtilmektedir. Katılımcılar ile yapılan görüşmelerde acenta ile ilişkiler hususunda en yoğun şekilde dile getirilen şikayet türü "acentaya farklı bilgi aktarımı" şeklinde gerçekleşmiştir. Bu konuda yapılan belli başlı yorumlar şu şekildedir:

“Acentalar ile ilişskilerimizi kötü şekilde etkileyecek geri dönüşler yapılabiliyor. Bu da bizim doğrudan işimize zarar veren bir husus." K5

"Otelimizi beğenmeyen veya otelde sorun yaşayan kimi turist rehberleri acentaya işletmemiz ile ilgili aslı olmayan bilgiler verebiliyor. Sunulan hizmeti kötüleme, gerçek olmayan eksik hizmet şikayetinden tutunda kahvaltı gecikmeleri vs. pek çok şey ile karşılaşıyoruz" K14

"Bakın geçen ay başımıza geldi. Rehber uyandırma saatini ve kahvaltı saatini tur planından yarım saat geç olarak bize bildirdi. Tabi bizim tur planına dair bilgimiz yok verilen direktif doğrultusunda işlemler gerçekleşti. Gecikme sebebi ile o gün tur iki yere eksik girmiş ve turistler acentaya hem şikayette bulunmuş hem de geri ödeme istemişler, rehbere sorduklarında ise otel geç uyandırdı hizmeti geç sağladı demiş. Aslı astarı yok ama böyle bir şeyi de kanitlama şansımız yok. Neyse ki acenta uzun zamandır çalıştığımız bir işletmeydi ve kendilerini inandırdık diye düşünüyorum” K16

Yaşanan bu şikayetler dışında katılımcılar turist rehberlerinin, konaklama işletmesi ile paylaşılan tur planından farklı hareket etmesi ve farklı otel talebi gibi sorunlar yüzünden seyahat acentaları ile sıkıntı yaşayabildiklerinden bahsetmiştir. Bu konu ile ilgili yapılan belli başlı yorumlar şu şekildedir:

"Acenta ile tur öncesi anlaşma yapılır, daha sonrasında tur saatleri hususunda da mutabakata varılır. Kimi turlar akşam yemeğine yetişemez veya çok erken çıkacă̆ından ön hazırlıklar yaparız. Fakat kimi turist rehberlerinde inatla kendi planlarını uygulatma çabası görüyoruz." K4

"Otele gelmesi gerekenden 3 saat önce gelen bir grubu odalara yerleştirmek bizim için ciddi bir sorun. Nihayetinde beş yıldızlı 100 odalı bir otel değiliz. Şehir gezisini kafasına göre değiştiren kimi rehberler otele istedikleri an istedikleri saate girebilirmiş gibi hiç bize haber verme ihtiyacı dahi duymadan giriş yapmak istedikleri durumlarla karşılaşabiliyoruz. Bu hem oteldeki mevcut turistleri hem gelen gruba ait turistleri gerçekten gerebiliyor." K5

"Bu bölgedeki konaklama işletmeleri konaklardan restore edilmiş küçük işletmeler. Oda sayıları limitli. Dolu sezonda daha odalar boşalmadan üstelik daha öncesinde bir saat hususunda acenta ile mutabakata varmamiza rağmen rehberlerin şahsi davranışları bizi çok zor duruma sokuyor." $\mathrm{K} 7$

"Çok değil ama birkaç defa başımıza geldi. Rehber otele girer girmez şöyle bir etrafi süzüp ben burada asla kalmam diyerek farklı otelde oda talebinde bulunuyor. 
Turist Rehberliği Dergisi (TURED) \& Y11. 2020, Cilt. 3, Sayı. 2

Journal of Tour Guiding (JOTOG) \& Year. 2020, Volume. 3, Issue. 2

\section{Üstelik bunu grubun yaninda da yapana denk geldik, Bana kötü oda verdiler diye de hemen acentaya şikayet etti. " $\mathbf{K} \boldsymbol{8}$}

"Burada konaklarımı bazen herkese hitap etmeyebiliyor. Ama konaklart da en iyi bilmesi gereken kişiler rehberler. Bazıları otelde kalmak istemiyor. Üstelik bize başka otelde oda ayarlamamız konusunda bask yapmaya çalışıyor. Ayıp bir davranış çok rahatsılık verici" $\mathrm{K12}$

\section{Sonuç ve Öneriler}

Gerçekleştirilmiş olan bu çalışma Türkiye'de yerli ve yabancı turizm hareketlilikleri açısından son derece önemli bir destinasyon konumundaki Safranbolu ilçesinde gerçekleştirilmiştir. Çalışma alanının bu bölge olarak seçilmesi de destinasyona gelen turların tek gece de olsa yoğun konaklama yapması sebebi ile pek çok işletmenin bölgede yıllardır tecrübe kazanmasına olanak vermiş ayrıca turlar vasıtası ile pek çok turist rehberinin aktif olarak bölgede bulunma sıklığından kaynaklanmaktadır. Çalışma vasıtası ile konaklama işletmelerinin turist rehberlerine yönelik şikayetlerinin tespit edilmesi amaçlanmıştır. $\mathrm{Bu}$ kapsamda ise 16 konaklama işletmesinin katılımı ile yarı yapılandırılmış görüşmeler gerçekleştirilmiştir. Çalışmanın bulgularının analiz edilmesi ile beraber çeşitli sonuçlara ulaşılmış, sonuçlardan hareketle yapılan tartışma sonucunda belirli öneriler getirilmiştir.

Özellikle bölgede yeni çalışmaya başlayan, dolayısı ile bölge dinamiklerini, çalışma yapısı ve kültürüne aşina olmayan turist rehberleri ile daha çok sorun yaşandığ 1 , şikayete sebebiyet verecek durumlar ile karşılandığı gözlenmektedir. Bunda özellikle Safranbolu'da gerçekleştirilen konaklamaların, restore edilerek işletmeye açılmış küçük konaklarda gerçekleşmesi bir sebep olarak gösterilebilir. Genelde Anadolu turlarında en az üç yıldız ama ağırlıklı olarak dört ve beş yıldızlı konaklama işletmelerinde kalan turist rehberlerinin etnografik ve kültürel yönü ağır basan, büyük otellere göre oldukça küçük ve eski donanıma sahip olan odalarına alışma ve kabullenme sürecinin bu şikayetlerde önemli bir etkisi olduğu düşünülmektedir.

Turist rehberlerine dair dile getirilen şikayetlerden biri, turist rehberlerinin konaklama işletmesine girişten sonra ortaya çıkan otel-müşteri problemlerine karşı ilgisiz davranması, arabulucu görevi üstlenmeyip hatta kimi durumlarda müşteriyi kışkırtıcı tavırlar belirtilmiştir. $\mathrm{Bu}$ şikayetlerin aynısı Çakmak ve Akyurt Kurnaz (2020)'ın seyahat işletmelerinin turist rehberlerine yönelik şikayetleri konulu çalışmalarında seyahat işletmelerince dile getirilen sorun ile birebir örtüştügü görülmektedir. Kanlı (2019)'nın çalışmasında da turist rehberlerine yönelik şikayetlerin \%18'i kabalık \%16's ilgisizlik olarak tespit edilmiştir. Bu nokta çalışmanın alan yazını ile uyum gösterdiği söylenebilir.

Çalışmada dile getirilen ve şikayet sebebi olarak gösterilen sıkıntılarından biri turist rehberlerinin seyahat acentası ya da otobüs kaptanı ile yaşadığı sıkıntıları konaklama işletmelerine de yansıtmasıdır. Bu şekildeki davranışlar hem konaklama işletmesi personeli ile olan ilişkiler hususunda sorun yaratırken hem de turistin işletme ile olan ilişkilere de etki ettiği görülmüştür. Avcı ve Doğan'ın (2018) yapmış oldukları çalışmada da turist rehberlerine yöneltilen şikayetlerden biri turda yaşanan sorunların sorun ile alakası olmayan kişi ve kurumlara yansitılması durumudur. Burada turist rehberlerinin tur süresince iletişim halinde bulunduğu diğer işletme ve şahısları birbirinden farklı olarak değerlendirmesi gerekliliği söz konusudur. Buradan hareketle aslında çalışma kapsamında elde edilen en önemli sonuçlardan biri de yaşanan çoğu şikayetini birbiri ile bağlantılı olduğu ve bir diğer adımı tetiklediği yönündedir. Acenta ile yaşanan sorun konaklama işletmesine sirayet ederken bu süreçten negatif etkilenen turist grubu da konaklama işletmesi içerisinde sorun yaşayabilmektedir. 


\section{IIIIII}

Turist Rehberliği Dergisi (TURED) \& Y1l. 2020, Cilt. 3, Sayı. 2

Journal of Tour Guiding (JOTOG) \& Year. 2020, Volume. 3, Issue. 2

Konaklama işletmeleri turist rehberlerinin aşırı talepkar olması gibi konulardan şikayetçi olduğu görülmektedir. Bu sorun otel işletmelerinin daha kurumsal bir yapı içerisinde hareket edip, konaklayacak turist rehberine yoruma yer birakmayacak bilgilendirme notlarının yönlendirmesi ile çözülebilir. Bu uygulama özellikle konaklama işletmesinde ilk defa kalan turist rehberlerine uygulanabilir. Aynı durum turist rehberine yönelik yapılan kaba tavırlar ve işveren tarzı rahat davranışlarda da söz konusudur. Bu yönde gelen şikayetleri incelediğimizde özellikle konak işletmelerinde daha yoğun olduğu gözlenmiştir.

Turist rehberlerinin tur programına aykırı davranarak otele verilen saatten erken ya da geç giriş yapmaları da bir şikayet unsuru olarak sıklıkla dile getirilen konulardan biridir. $\mathrm{Bu}$ husus son derece hassas bir konu olarak iki taraf açısından da ele alınması gereken bir durumdur. Safranbolu bölgesinde otellerin az oda sayısına sahip olması ve oteldeki misafir sirkülasyonunun bu yoğunluk ve kısıtlılık çerçevesinde ayarlandığı bir gerçektir. Bir tur programının belirlenen planda sapma oranı ise şikayete sebep olan bu durumda büyük bir rol sahibidir. Eğer tur teyit edilen saatlerden çok daha önce veya sonra giriş yapıyorsa bu konaklama işletmesi için gerçekten bir sorun unsuru haline gelecektir. Öte yandan konaklama işletmeleri de tur esnasında pek çok hesaba katılmayan aksilik veya sorunun meydana gelebileceği kısa çaplı erken ya da geç varışların olabileceğini hesaplamalı ve esneklik düzeylerini arttırıcı önlemler almalıdır. Bunda grupların kabul ediliş saatleri arasındaki süreyi arttırmak çözüm olabilir. Öte yandan Kanlı (2019)'nın çalışmasına göre turist rehberleri hususunda turistler tarafından yapılan şikayetlerin \%10'u tur programına uymama olarak gösterilmektedir.

Şikayetlerin önüne geçilmesi ve sektördeki paydaşlar arası anlaşma ortamının sağlanmasi için konaklama ve turist rehberliği meslek birlikleri ortaklaşa bir eğitim semineri hazırlayabilir. Günümüzde eğitim seminerlerinin yüz yüze gerçekleşmesi gerekliliğinin ortadan kalktığı düşünülürse böyle bir çalışmanın maliyeti de düşük olacaktır. Bu eğitim ile birlikte özellikle mesleğe yeni giren turist rehberlerine iletişim, etik ve mesleki değerler konularında bilgilendirmeler yapılmalıdır. Bu eğitimlerin turist rehberlerinin konaklama işletmelerine dönük şikayetleri de göz önüne alınarak konaklama işletmelerine de uyarlanması gerekmektedir.

$\mathrm{Bu}$ çalışma konaklama işletmelerinin turist rehberlerine yönelik şikayetlerinin tespit edilmesi amacı ile gerçekleştirilmiştir. Çalışmanın Safranbolu ilçesinde işletilmekte olan konaklama işletmelerinde gerçekleştirilmiş olması çalışmanın sınıllılıkları kapsamında değerlendirmek mümkündür. Çalışma sınırlı sayıda turist rehberi üzerine yapılan şikayet temelli araştırma ile karşılaştırıldığında, alan yazınında dile getirilen şikayet maddelerini desteklediği, daha öncesinde seyahat acentaları ve turistler tarafından dile getirilen belli başlı şikayetlerin konaklama işletmeleri tarafından da dile getirildiğini göstermektedir.

$\mathrm{Bu}$ çalışmayı ilerletmek ve bu alanda çalışmak isteyen araştırmacılar, farklı turistik destinasyonlardaki konaklama işletmeleri üzerinde aynı çalışmayı yürütebilir. Böyle farklı özelliklerdeki destinasyonlar arasındaki şikayet farklılıkları da görülebilir nitelikte olacaktır. Ayrıca turist rehberlerinin konaklama işletmelerine yönelik şikayetlerinin öğrenilmesine yönelik yapılacak çalışmalar alan yazınında konu bütünlüğü sağlayacak ve bir boşluğu dolduracak nitelikte olacaktır. 


\section{Kaynakça}

Avcı, E. \& Doğan, S. (2018). E-Şikâyetler Turist Rehberleri Hakkında Ne Söylüyor, Seyahat ve Otel Işletmeciliği Dergisi, 15(1): 133-148.

Batman, O. Yıldırgan, R. ve Demirtaş, N. (2001) Turizm Rehberliği, İstanbul: Değişim Yayınlar1.

Camilleri, M. A. (2018). Travel Marketing, Tourism Economics and the Airline Product: An Introduction to Theory and Practice, Switzerland: Springer

Ceylan, S. \& Somuncu, M. (2016). Kültür Turizmi Alanlarında Turizmin Çeşitlendirilmesine Eleştirel Bir Bakış: Safranbolu UNESCO Dünya Miras Alanı. Uluslararası Türk Dünyası Turizm Araştırmaları Dergisi, Nisan-1(1), 53-64.

Cohen, E. (2004). Contemporary Tourism: Diversity and Change. Amsterdam: Elsevier

Cohen, E.H., Ifergan, M. \& Cohen, E. (2002). A New Paradigm in Guiding: The Madrich Role Model. Annals of Tourism Research, 22(4), 818-932.

Çakmak, T. F. \& Akyurt Kurnaz, H. (2020). Seyahat Acentalarının Turist Rehberlerine Yönelik Şikâyetleri Üzerine Nitel Bir Araştırma. Ankara Hacı Bayram Veli Üniversitesi Turizm Fakültesi Dergisi, 23 (1), 78-96.

Çetin, G. \& Yarcan, S. (2017). The Professional Relationship Between Tour Guides and Tour Operators. Scandinavian Journal of Hospitality and Tourism, 17(4), 347-357

Ejarque, J. (2005). Destinos Turísticos De Éxito: Diseño, Creación, Gestión Y Marketing. Madrid: Piramid. ISBN 84-368-1928-4.

Ekiz, E., Norman, A. \& Cathy H. (2012). Development of a Tourist Complaint Constraint (TCC) Scale. Scandinavian Journal of Hospitality and Tourism, 12(4), 373-399.

Foley, M. Lennon, J.J. \& Maxwell, G.A. (1997). Hospitality, Tourism and Leisure Management: Issues in Strategy and Culture. London: Cassell.

Giese, J.L. \& Cote, J.A. (2000). Defining Consumer Satisfaction. Academy of Marketing Science Review, 1,1-24.

Hansen, A.H. \& Mossberg, L. (2016). Tour Guides' Performance and Tourists' Immersion: Facilitating Consumer Immersion by Performing a Guide Plus Role. Scandinavian Journal of Hospitality and Tourism, 17(3), 259-278.

Holloway, J.C. (1981). The Guided Tour: A Sociological Approach. Annals of Tourism Research, 8(3), 377-402.

Kanlı, K. (2019). Turist Rehberlerine Yönelik E-Şikâyetlerin İçerik Analizi ile İncelenmesi, Turist Rehberliği Dergisi, 2(1), 10-17.

Karabük Valiliği. (2020). Safranbolu İlçesi. http://karabuk.gov.tr/safranbolu-ilcesi (Erişim Tarihi: 17.09.2020)

Kılınç K.U. (2004). Şikâyet Yönetimi ve Yetkilendirme: Resort Otel İncelemesi (yayınlanmamış yüksek lisans tezi). Adnan Menderes Üniversitesi Sosyal Bilimler Enstitüsü: Aydın.

Kruczek, Z. (2013). The Role of Tourist Guides and Tour Leaders in The Shaping of The Qualty of Regional Tourist Products. University of Business in Wroclaw.

Larsen, J. \& Meged, J.W. (2013). Tourists Co-Producing Guided Tours. Scandinavian Journal of Hospitality and Tourism, 13(2), 88-102.

Murphy, P., Pritchard, M.P. \& Smith, B. (2000). The Destination Product and Its Impact on Traveler Perceptions. Tourism Management, 21(1), 43-52.

Oliver, R.L. (1997). Satisfaction: A Behavioral Perspective on The Consumer. New York: Irwin/McGraw-Hill.

Özdemir, Ü. (2011). Safranbolu'nun Kültürel Miras Kaynakları ve Korunması. Eastern Geographical Review, 26, 129-142. 
Turist Rehberliği Dergisi (TURED) \& Y1l. 2020, Cilt. 3, Sayı. 2

Journal of Tour Guiding (JOTOG) \& Year. 2020, Volume. 3, Issue. 2

Patton, M. Q. (2005). Qualitative Research. New York: John Wiley \& Sons, Ltd.

Petriana, B. (2015). Online Complaints About Wellington's Luxury Hotels. TOUR 410 Dissertaion. Victoria University of Wellington.

Rabotic, B. (2010). Tourist Guides In Contemporary Tourism. International Conference on Tourism and Environment. Sarajevo 04-05 March. 353-364.

Ruiz, E.C. Gonzales, G.B. \& Zamora, D.T. (2018). Destination Image, Satisfaction and Destination Loyalty In Cruise Tourism: The Case Of Malaga (Spain). Tourism \& Management Studies, 14(1), 58-68.

Safranbolu Turizm Danışma Bürosu, (2020). Safranbolu. https://safranboluturizmdanismabur osu.ktb.gov.tr/TR-155851/ safranbolu.html (Erișim Tarihi: 17.09.2020)

Sandaruwanii, R.C. ve Gnanapala, A.C. (2016). The Role of Tourist Gu1des and Therr Impacts on Sustainable Tourism Development: A Critique on Sri Lanka. Tourism, Leisure and Global Change, 3(1), 62-73.

Schmidt, C.J. (1979). The Guided Tour: Insulated Adventure. Journal of Contemporary Ethnography, 7(4), 441-467.

Temizkan, R. \& Ar, H. (2017). Turist Rehberlerine Yönelik E-Şikâyetlerin Analizi, Akademik Bakı̧ Dergisi, 15: 273-286

WALES (2016). Handling Complaints Factsheet. https://businesswales.gov.wales/ tourism/sites/tourism/files/documents/WG28810\%20Complaints\%20Factsheet\%20E\%20 \%5BPDF\%5D.pdf (Erişim Tarihi: 17.09.2020)

Wynn, J.R. (2005). Guiding practices: Story Telling Tricks for Reproducing The Urban Landscape. Qualitative Sociology, 28(4), 399-417.

Yarcan, S. (2007). A Conceptual Evaluation of Code of Ethics for Professional Tourist Guides (In Turkish). Anatolia: Turizm Araştırmaları Dergisi, 18(1), 33-44.

Yazıcıoğlu, H. (2001). Küçük Osmanlı'nın Öyküsü Safranbolu Tarihi, İstanbul: Şato Yayınları

Yetgin, D., Azade Çalık, Ö. \& Çiftçi, G. (2018). Turist Rehberlerine Yönelik Sanal Şikâyetler: www.sikayetvar.Com Örneği, içinde: Turist Rehberliği Üzerine Güncel Arașttrmalar, (Ed: Hacıoğlu, N., Avcıkurt, C., Kılıç, A., Ulusoy Yıldırım, H.), 622-637Ankara: Detay Yayıncilik.

Yıldırım, A. ve Şimşek, H. (2016). Sosyal Bilimlerde Nitel Araştırma Yöntemleri (11. Baskı), Ankara: Seçkin Yayıncılık.

\section{ETIKK ve BILIMSEL İLKELER SORUMLULUK BEYANI}

$\mathrm{Bu}$ çalışmanın tüm hazırlanma süreçlerinde (veri toplama, yazım vb.), tüm etik kurallara ve bilimsel atıf gösterme ilkelerine riayet edildiğini, herhangi bir hataya mahal vermemek için yayımdan önce makalenin bir intihal programı aracılığıyla da kontrol edildiğini yazarlar beyan eder. Ayrıca yazarlar aşağıda sıralanan hususları kabul etmiștir:

1. Çalışmada yer alan ve kullanılan tüm kaynaklara, bilimsel araştırma yöntemleri ve etik ilkeler doğrultusunda atıf yapılmıştır. 2. Calışmada tüm yazarların akademik-bilimsel olarak doğrudan ve ortak katkısı vardır.

3. Bu çalışma, yazarların özgün bir çalışmasıdır.

4. Bütün yazarlar dergiye gönderilen makaleyi görmüş ve sonuçlarını onaylamıştır.

5. Çalışmada kullanılan denek/deneklere ilişkin herhangi bir etik ihlal yapılmamış, kullanılan tüm veri toplama yöntemlerinde bilimsel etik ilkelere göre hareket edilmiştir.

6. Calıșma daha önceden bilimsel bir toplantıda sunulan özet veya bu çalıșmanın daha kısa hali ise, makalede bu durum belirtilmiştir

7. Çalışmada, hiçbir suç unsuru veya kanuna aykırı ifade bulunmamakla birlikte, araștırma yapılırken kanuna aykırı herhangi bir yöntem kullanılmamış olup, çalıșma ile ilgili tüm yasal izinler alınmış ve etik kurallara uygun hareket edilmiștir.

Aksi bir durumun tespiti halinde Turist Rehberliği Dergisi'nin hiçbir sorumluluğu olmayıp, tüm sorumluluk makale yazarlarına aittir.

Tarih $\quad: 23 / 11 / 2020$

Sorumlu Yazar $\quad$ : Tolga Fahri ÇAKMAK 